\title{
3D SURVEYING AND 3D RECONSTRUCTION OF ARCHITECTURE OF THE ROYAL PARK OF TIRANA
}

\author{
L. Corniello ${ }^{1 *}$ \\ ${ }^{1}$ University of Campania “Luigi Vanvitelli” Dept. of Architecture and Industrial Design, Aversa, Italy - \\ luigi.corniello@unicampania.it
}

\author{
Commission VI, WG VI/4
}

KEY WORDS: Survey, 3D reconstruction, 3D modelling, landscape, Park, Tirana, Albania

\begin{abstract}
:
The research proposes the study of the Royal Park of Tirana in Albania, with particular reference both to the vegetation system, such as tree-lined avenues, ornamental gardens and vegetable gardens, and to the architectural elements such as the Villa, the Church, the gardener's house, the generator house and greenhouses. The few iconographic documents consist of the plans of the Grand Park of Tirana in 1957 and 1980, where some large buildings can be identified. The bibliography is relegated to the few citations found in the volumes illustrating the works of the two architects G. Bosio and G. Bertè. For the activities of knowledge of the Royal Park and of the architectural elements, in addition to the classical techniques of direct and indirect survey, we took into account the Ryobi laser instrumentation applied on portable computer support both tablets and smartphone. This digital system allows an immediate view of the relevant data on the photographic image taken by the support, transforming it into a dynamic datum. In the first phase, the relevant activity envisaged a basic knowledge extended to architectural organisms and green systems with a primitive geometric model; subsequently, measurements of architectural details, structures and the digital model were made. Appropriate photographic documentation was produced in addition to bibliographic, archival, and iconographic surveys.
\end{abstract}

\section{INTRODUCTION}

The research, based on the assumptions of the scientific sector and starting from the study of historical-iconographic sources, presents the results of the architectural and environmental surveys in terms of types and morphologies that expose the geometric and structural beauty of architecture and the system vegetation of the Royal Park of Tirana. In the activity of reading the identity issues the design disciplinary, the relationships between representation and measurement, the graphic aspects and the material and immaterial values of the places are identified, understood as traces of the past to be compared to the architectural and environmental contingencies of the present. The Royal Park, located on the Mulleti hill, covers an area of 74 hectares and includes six buildings such as the Odeon, the Royal Palace, the Chapel, the complex of greenhouses, the generator's house and the gardener's house. Four green areas like the avenue of cypresses, the avenue of the oleanders, the garden with the belvedere and the lake. The first hypothesis of Giardino Reale, presumably commissioned by King Zog, was conceived by the architect Florestano di Fausto (1890 - 1965), subsequently modified by the engineer Giulio Berté and the architect Gherardo Bosio (1903 - 1941) and finally realized by the architect Ferdinando Poggi (1902 1986). The research involved a conspicuous analysis of the archival documentation - such as drawings, photographs, sketches and notes - concerning the examination of the design and executive drawings of the engineer Giulio Berté carried out in the Arkivi Qëndror Teknik i Ndërtimit (Technical Building Archive) of Tirana. The study also concerned the architect Bosio's drawings, including a representation of the Villa Reale in the center of a perspective with an amphitheater at the base demonstrating the emphasis on the representative role proposed for the residence by the same designer. There are also numerous interventions by landscapers and artists who have left extensive documentary traces of the interventions carried out and proposed such as Pietro Porcinai (1910 - 1986) and Antonio Maraini (1886 - 1963).
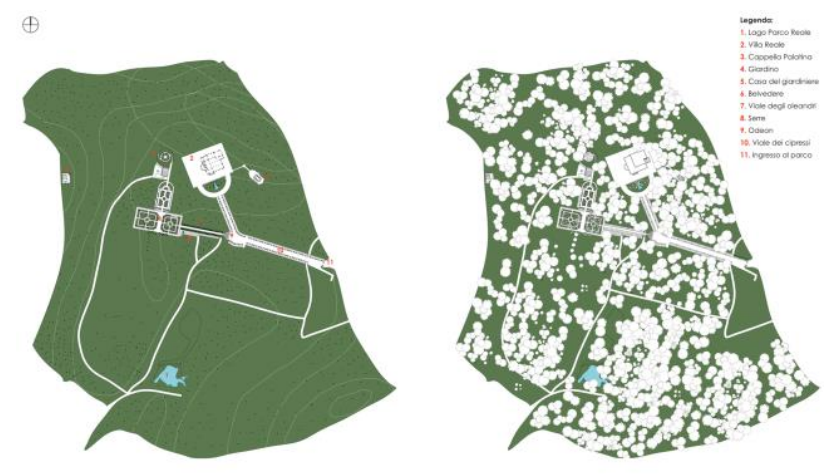

Figure 1. The Royal Park of Tirana. General plan with typology identification (on the left) and roof planimetry (on the right).

\section{THE REDRAWING FOR 3D RECONSTRUCTION}

The Royal Park is represented in three planimetries preserved respectively, the first dating back to 1939 and the second in 1941 at the Arkivi Qëndror Teknik i Ndërtimit in Tirana, the

\footnotetext{
* Corresponding author
} 
third, in 1942, at the Gherardo Bosio archive. In the first document the Park is depicted according to the hypothesis of 1939 where it is possible to identify the Villa Reale with its access avenue, the belvedere, some service rooms and, in the lower parts of the plan, the racecourse. The structure of the sports facility occupies most of the floor plan for horse racing, that is to say a playful activity, particular attention. Of particular interest is the arrangement of the spaces in front of the Villa where an elliptical parterre delimits the scenographic and representative green portion from the one-way driveway area. The spaces currently occupied by the Chapel, instead, are designed to serve the Villa itself with a private garden and a labyrinth, in the style of 18th century European Royal Gardens.

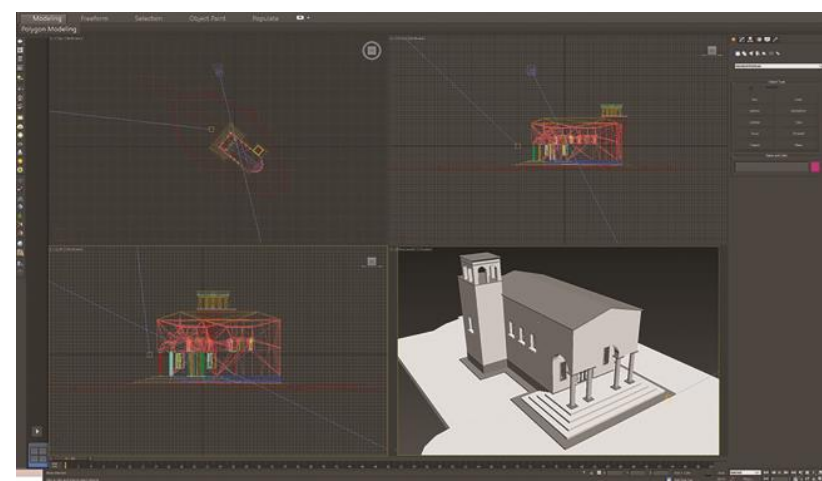

Figure 2. The Royal Park of Tirana. 3D model of the Church created by the digital platform.

In the second document, the whole vegetation system is defined in the almost definitive configuration: the thick crown of the trees is represented with the definition of a first hypothesis of Italian and English gardens in addition to the identification of the Villa alone. The service buildings are not designed but flat spaces are identified for their subsequent location. The jumps of altitude and the pedestrian and vehicular paths to enjoy the entire Park are determined: the avenue of cypresses pours into a pedestrian path that leads to the Italian garden, and to the next flower garden. The sports facilities, eliminated the hypothesis of the construction of the racecourse, are relegated to sports fields located in the lower part of the Italian garden. In the third plan, on the other hand, a project drawing from 1942, the Park with the garden system and the pedestrian and vehicular paths such as the cypress avenue, the Villa with a first parterre in front, are defined with greater graphic accuracy. Functional buildings such as the generator and the gardener's house and the military buildings along the perimeter. (Giusti 2012)

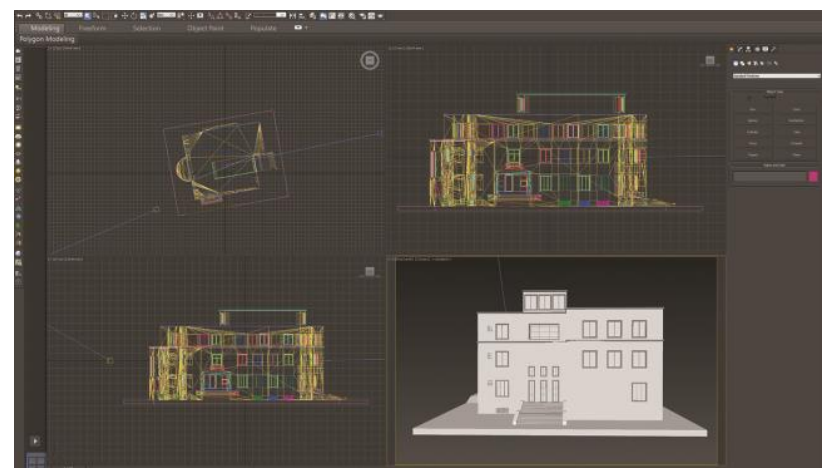

Figure 3. The Royal Park of Tirana. 3D model of the Villa Reale created by the digital platform.

The Villa Reale expands in the northern part with the winter garden, an architectural system on different levels shielded to the north by white cement walls designed to protect the precious tree species. The fifth stage of the Odeon defines the curvature of the avenue of cypresses expressing the architectural strength of the megalithic architecture of the mid-twentieth century. The gardens are defined, both the Italian one and the flower one, and the belvedere, an elevated structure that can be reached by two flights with curved steps, able to guarantee the view towards the gardens and the underlying forest, as well as the entire city of Tirana. In the lower part of the plan you can find the barracks composed of two linear blocks: the first site near the main entrance, the second in a rear position. The gardener's house, in the western part of the Royal Park, can be reached through three routes that lead respectively to the Villa, the Parku i Madh and

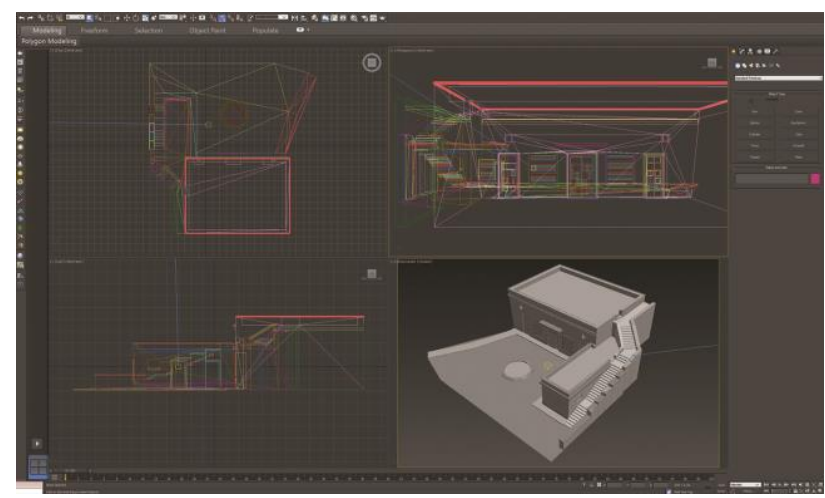

Figure 4. The Royal Park of Tirana. 3D model of the generator house made by the digital platform.

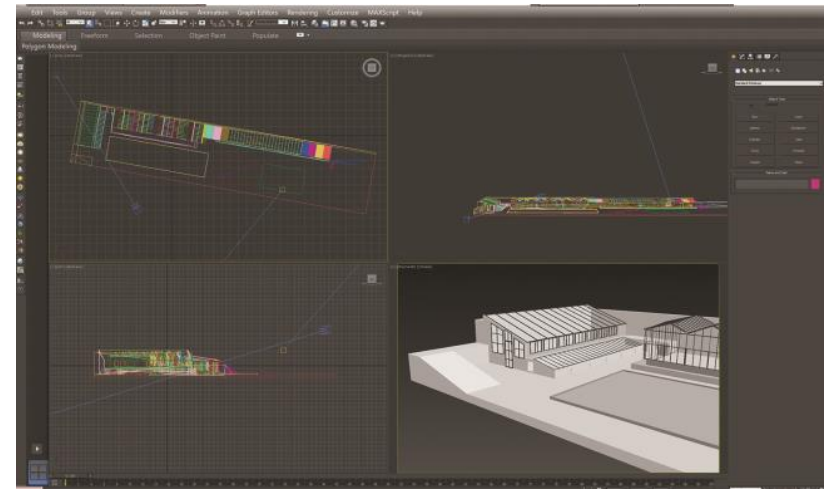

Figure 5. The Royal Park of Tirana. 3D model of the greenhouses realized by the digital platform.

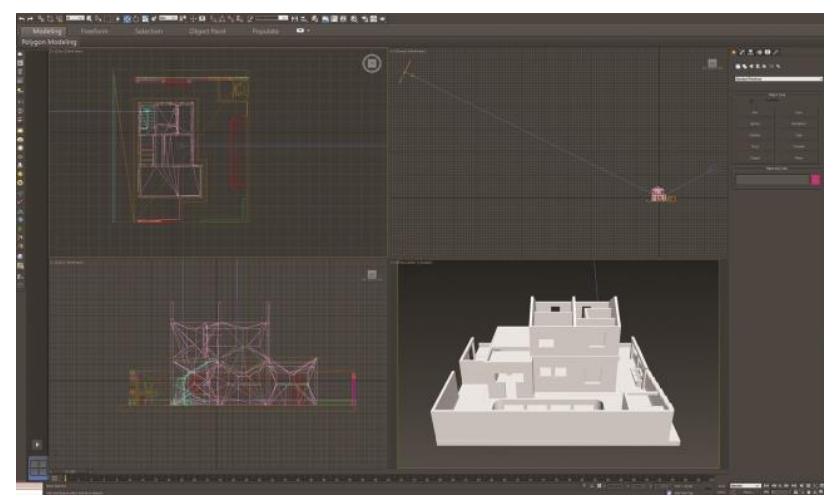

Figure 6. The Royal Park of Tirana. 3D model of the gardener's house made by the digital platform. 
the sports facility. Therefore, through the graphic reproposing, we intend to propose, the perceptive and codified interpretation of the existing reality, transmitting the heterogeneous and scientific content of the graphic image. (Nepravishta, 2012)

\section{THE SURVEY OF THE ARCHITECTURE AND LANDSCAPE}

The original project, dated 1935 , was signed by the architect Florestano di Fausto and included the Royal Palace, a Villa for the King and a building for the Princesses. After that date, the work of ideation passed to the engineer Giulio Bertè who, in 1937, relies on the landscape architect Pietro Porcinai for the design of the Park, which elaborates different solutions to define the design of the floors, the monumental staircase and some decorations. The engineer, very well known in Tirana, had made numerous residences for local aristocrats following rationalist styles and far from the classic forms of European Royal Villa. The works, following the indications of Berté himself, begin in 1938 but were interrupted in 1939 with the Italian invasion of Albania. In 1939 the intervention of the architect Gherardo Bosio was decisive, reinterpreting the project redesigning the geometries of the Villa and producing the executive drawings of the interior furnishings, the external and internal finishes and the definitive design of the garden with clear references to European Residences. In 1942 the architect Ferdinando Poggi, after the disappearance of Bosio, revised again the project of the Villa, of the gardener's house, of the Chapel and of the barracks and concluded the works in a short time. (Giusti 2012)

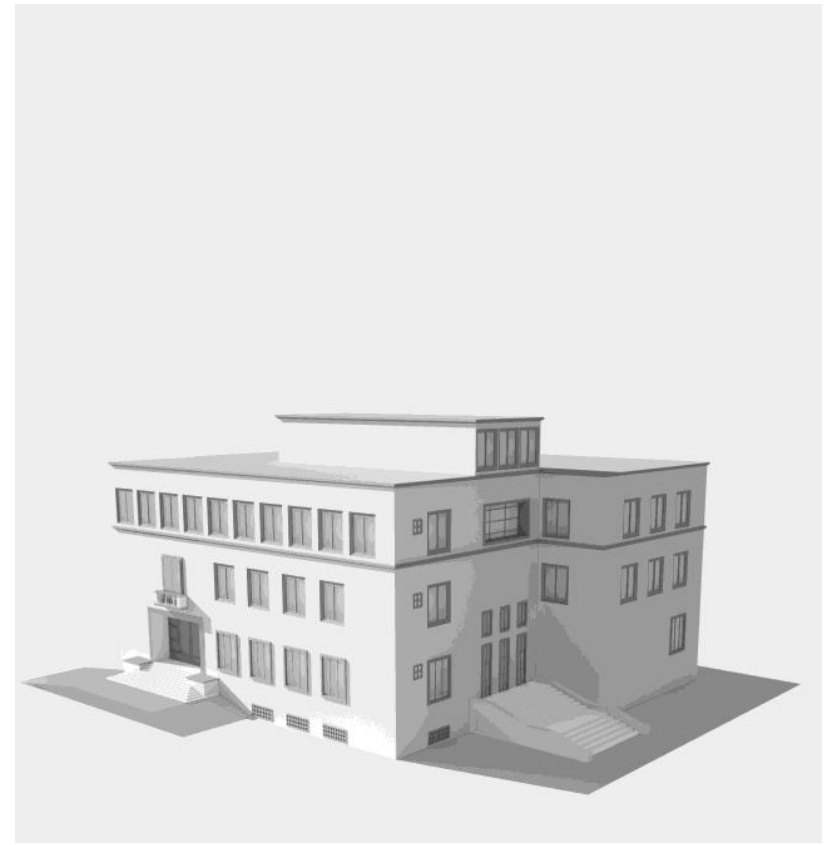

Figure 7. The Royal Park of Tirana. 3D survey of the Villa Reale.

The Villa Reale, is revised in the interior furnishing (previously designed by Bosio both in the drawings of the construction materials and in the choice of the skilled workers, the materials, the artists of reference of the time) and in the architectural composition with asymmetrical geometries in plan and in elevation as well as with apsidal volumes facing west. The current morphological layout of the Villa is on four levels, one of which is underground, and a flat roof. The load-bearing structure is in reinforced concrete with bricks, plastered facades and openings bordered by travertine jambs and closed by wooden doors and windows.

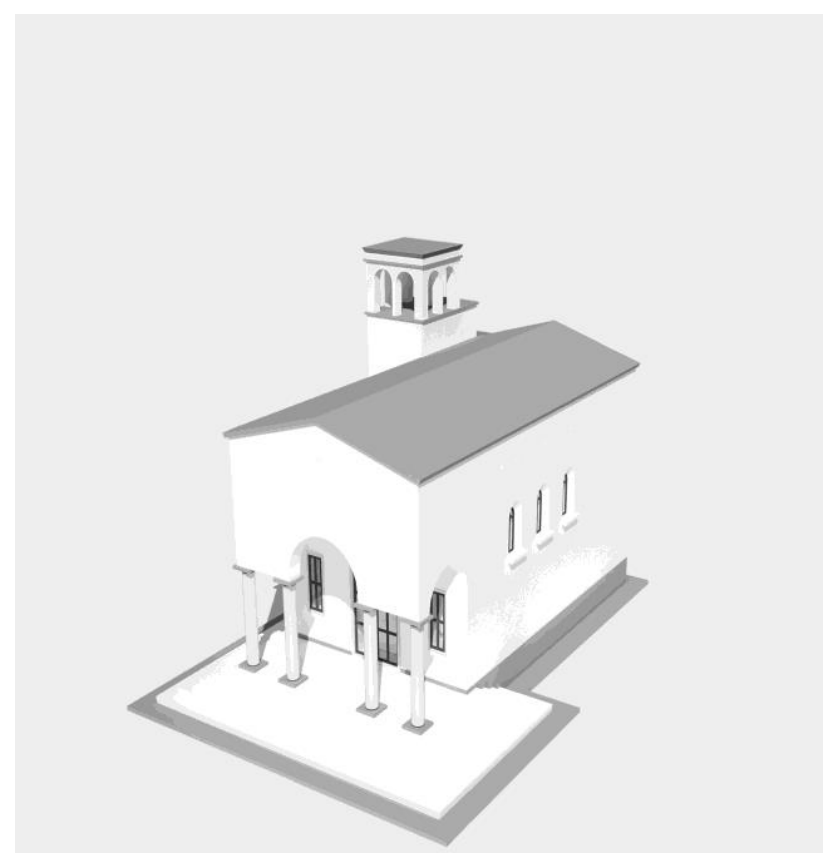

Figure 8. The Royal Park of Tirana. 3D survey of the Church.

The main facade, exposed to the south, is characterized by an entrance with 11 steps leading to the portal in travertine and a wooden door. The Chapel inside the Royal Park, known as the Palatine Chapel, stands on a promontory, was built in 1939 at the behest of Vittorio Emanuele III. The current layout is a single hall with a semicircular apse and stone paving. The main facade is preceded by a portico with four columns plastered and painted gray:

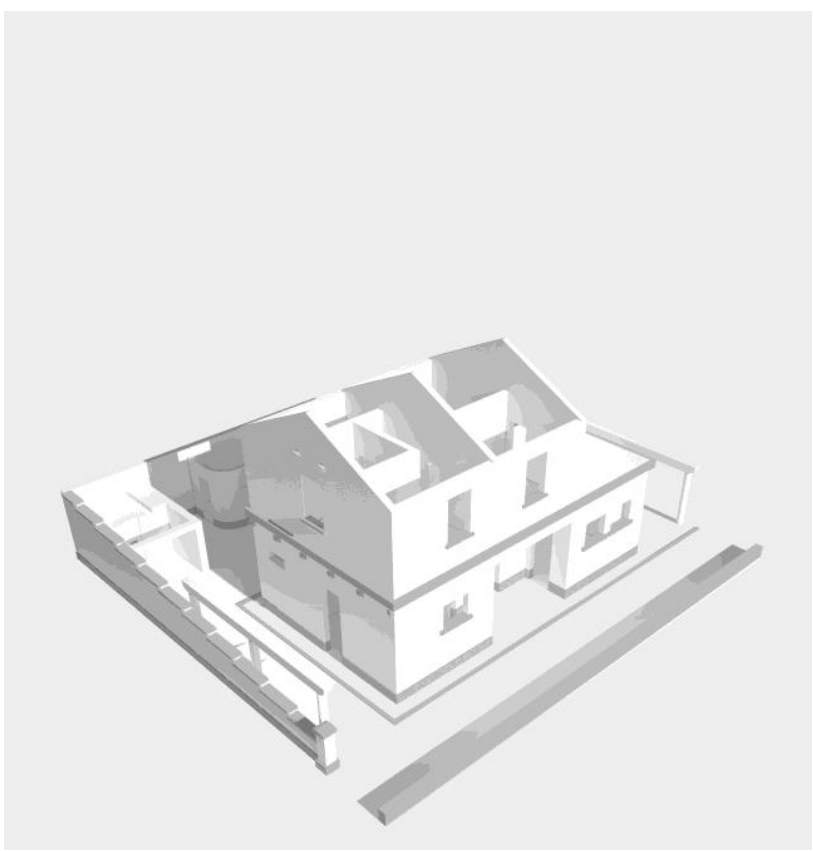

Figure 9. The Royal Park of Tirana. 3D relief of the gardener's house. 
the facades are also painted white and have four holes in the west, five windows in the east, one of which is located on the bell tower. In the part below the flower garden to the west of the Villa Reale, instead, the house of light is built, a basement structure with a flat roof from which, through a scenic ramp, leads to a first terrace, covering a technical volume of the same body architectural and, through a subsequent flight of stairs, to the square below with a central water basin. The western facade, which encloses the diesel generator for the production of electricity in the entire complex, is characterized by a central portal with shelter and two lateral entrances closed by wooden doors and windows; the two windows that intersect laterally with respect to the portal, of square shape, are distinguished by retractable shutters. (Giusti 2012).

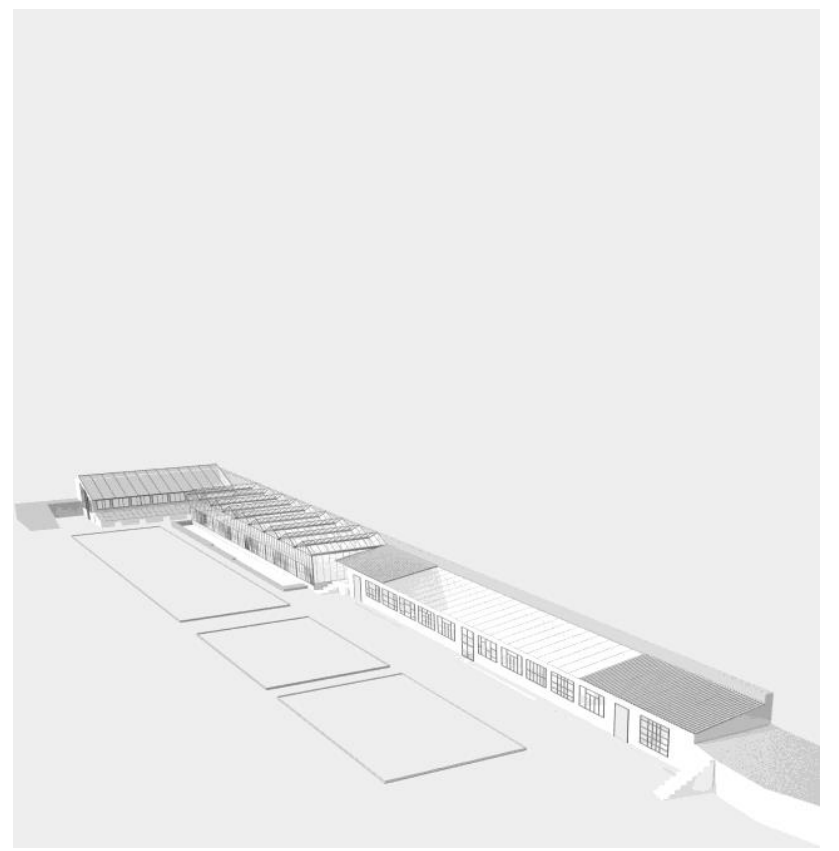

Figure 10. The Royal Park of Tirana. 3D survey of greenhouses.

In the southern part of the avenue of cypresses, sheltered from the north winds, there is the complex of greenhouses, built between 1941 and 1942 simultaneously with the gardener's house. The design idea was by the landscape architect Pietro Porcinai who, as shown in the archive documentation, outlines, in addition to the geometric shape, also the arrangement of the internal vegetation, the seasonal planting of vegetables and flowers, as well as the strategic layout of the forest behind. (Giacomelli 2012) The greenhouses follow the path below the avenue of oleanders separated from it by a vegetation system with a protective function from the north winds and a reinforced concrete containment wall on which the iron and glass structure rests. The complex is composed of four distinct identifiable volumes: the first to the west with a masonry base and a glass roof, the second, $50 \mathrm{~cm}$ higher than the floor, in iron and glass, the third in masonry, with an opaque roof and large openings exposed to the south and, finally, the fourth, a service building which serves as a storage area for equipment, vessels and for storing seeds. In 1943, the architect Ferdinando Poggi defines the current configuration of the Park according to the new requirements of the client and the guidelines coming from the styles of the European Gardner. The avenue of the cypresses is created, a driveway that from the entrance on Via Elbasan leads to the Villa Reale, characterized by a regular geometric mesh of two trees interrupted by seats, the central fountain in front of the
Villa with parterre, water chain and group sculptural. The avenue of the oleanders, a pedestrian path of 46 meters, and the sequence of the Italian-style gardens, of the flowers and of the belvedere are from the same period and by the same architect.

The Italian garden is characterized by two square vegetation polygons placed in line with the flower garden, the oasis of the entire Park, where tree species with seasonal flowering are planted. The path ends with the raised lookout system which is accessed through two symmetrical spiral staircases that follow the containment wall of the mound from which it is possible to admire the entire plant of the gardens and glimpse, through the thick vegetation, the underlying city of Tirana. The gardener's house stands on a two-level building with adjoining external services such as ovens and storage areas,

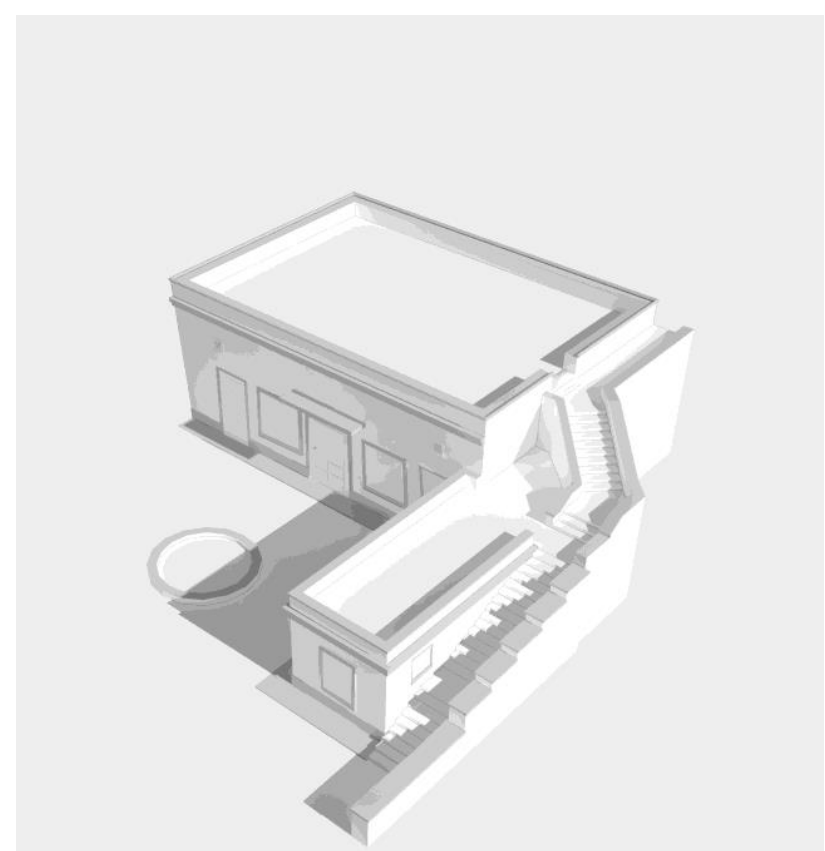

Figure 11. The Royal Park of Tirana. 3D survey of the generator house.

along a pedestrian path that slopes towards the west and away from the representative scenic system. The structure, now in a state of total abandonment, is invaded by the infesting vegetation and presents the total collapse of the roof: it preserves the flight of stairs that leads to the second floor and the bearing walls of the same level. The Poggi also redefines the paths in the Park and the border of some parts of the lake. The original basin presented three small lakes in succession, two of which disappeared and can now be identified in planimetry only through the identification of marsh vegetation. The today's mirror of water has a concrete border in the south part while in the north a wall in boulders, also exploiting the natural slope of the ground, prevents the leakage of water. (Posca et al. 2013)

\section{THE 3D RECONSTRUCTION AND 3D MODELING}

The theme of digital modelling is of great importance, since it allows to address, according to the disciplinary assumptions such as technical-instrumental and theoretical applications, the dynamics of design related to both traditional representation and digital innovation. With this science the aspect concerning the visualization is determined, a fundamental element for the communication of the object examined, through which it is 
possible to define the final graphic rendering compatible with the purpose of the survey activity, be it related to the knowledge of the existing is indicative for the protection and enhancement of the asset. The critical description of architecture, starting from the graphic reading of the typological imprints of the buildings of the past and from the morphological configurations, with reference to the discipline of design, makes explicit the awareness of the scientific and cultural foundations of representation methods aimed at understanding architecture: first through the design of the plan, of the section and of the elevation; moreover through the measurable threedimensionality of the axonometry and, finally, through the ideal spatiality of the perspective.

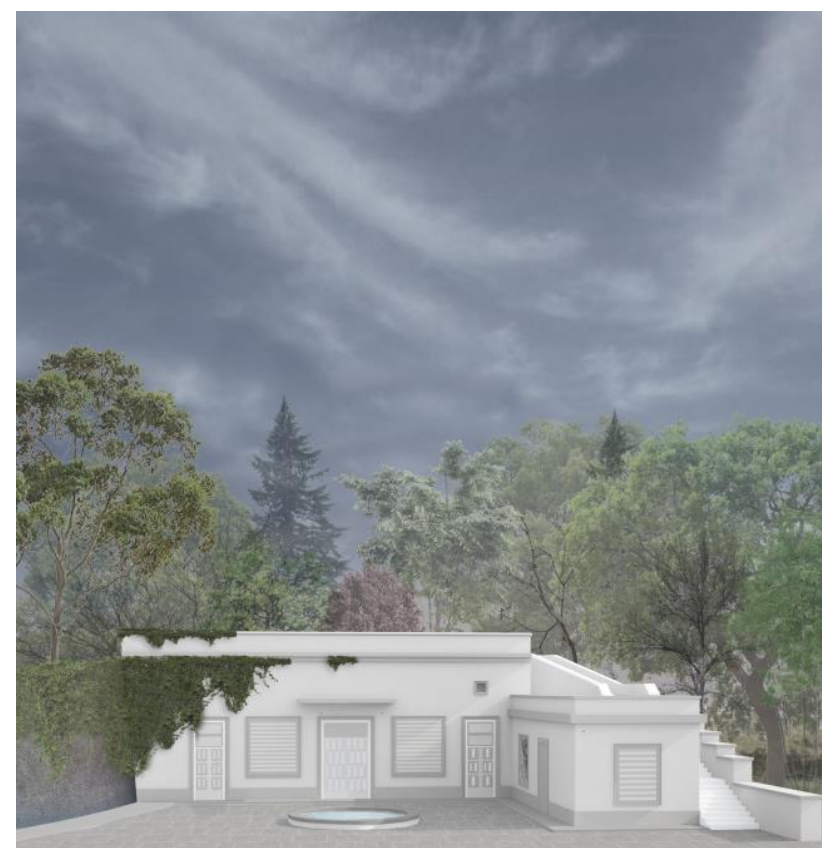

Figure 12. The Royal Park of Tirana. Render of the generator house.

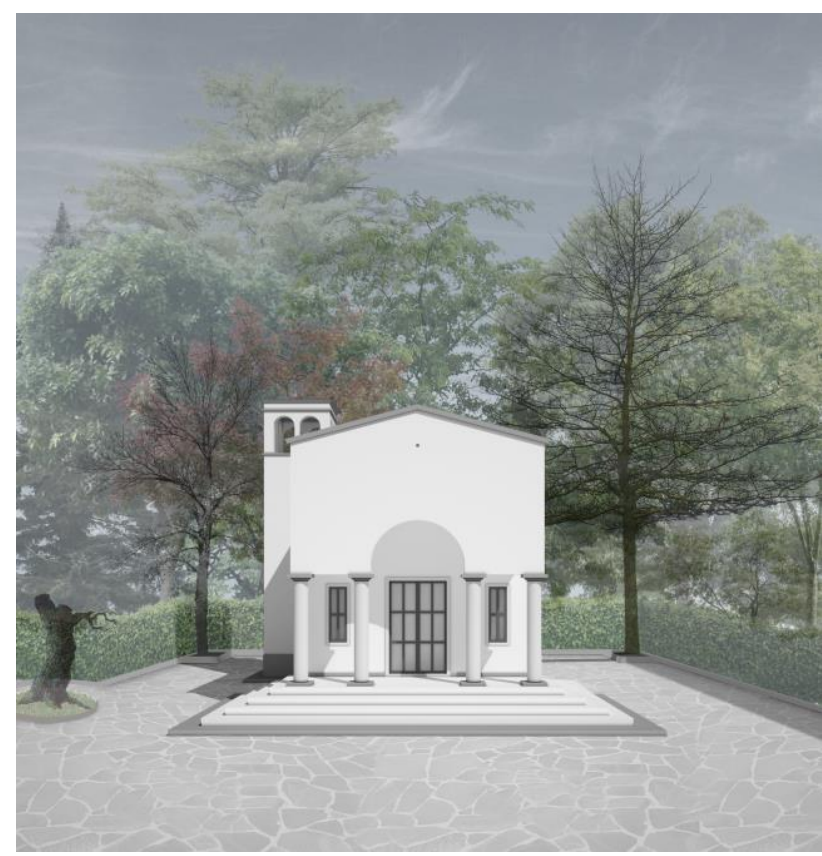

Figure 13. The Royal Park of Tirana. Render of the Church.
The new information technologies applied to geometry become a tool for restitution, analysis and information of the Royal Park of Tirana. (Corniello 2019)

In the illustrated graphic scene, the design of the architectures or the practice oriented to model the object as a form covers the main critical and theoretical exercise of method for digital technologies defining the questions of geometric nature necessary for the creation of virtual models. In this sense, the method of orthogonal double projections, parallel and central projections constitute the explication of one's scientific characters through their intrinsic capacity to bring out the thematic and ideal contents of architecture.

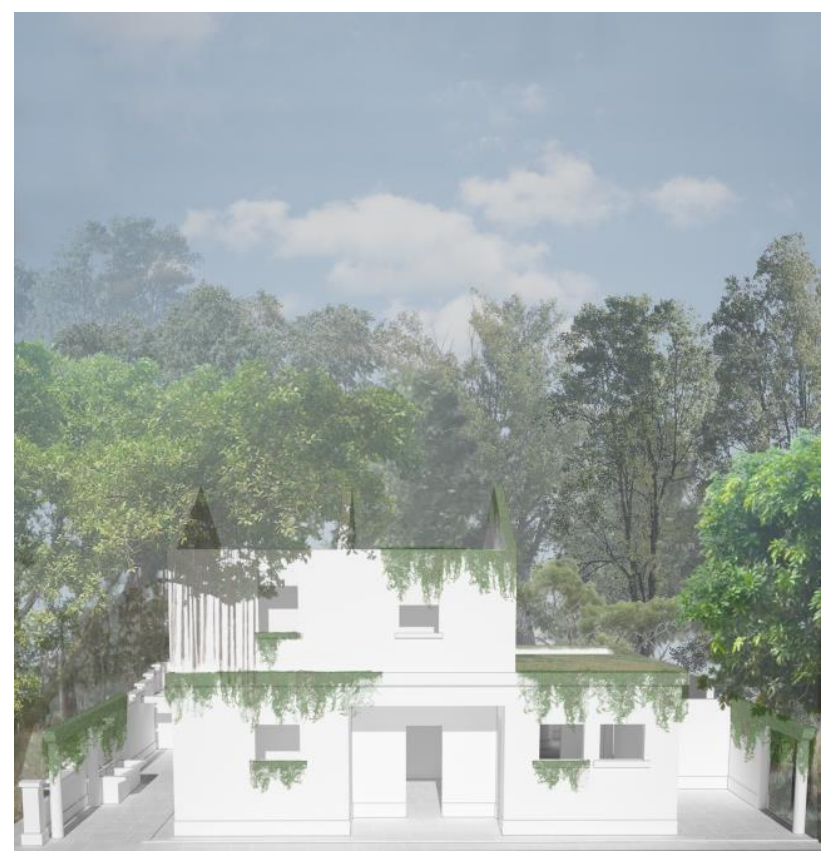

Figure 14. The Royal Park of Tirana. Render of the greenhouses.

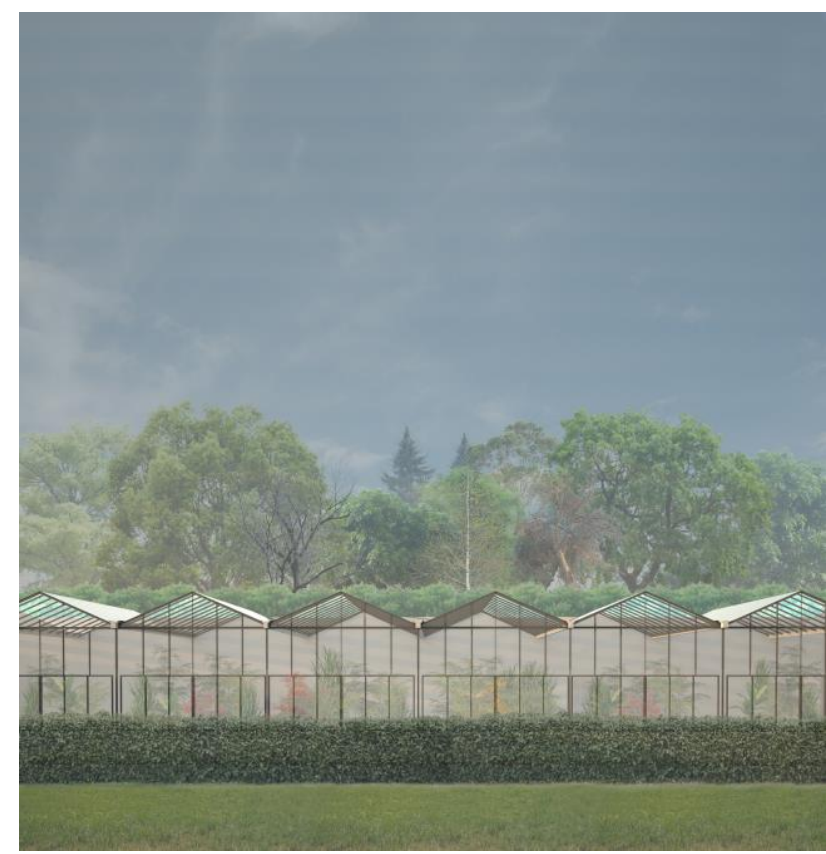

Figure 15. The Royal Park of Tirana. Render of greenhouses. 
The digital representation, as well as the implicit realization of models, in addition to covering a graphic role of threedimensional reproduction of the object, is a tool for verifying the congruence of conventional representations, such as plan, sections and elevations. The model is an ideal icon of reality and, relative to the morphology, it shows all the characteristics indicated by the drawing, specifying the best form and particularity, representing and manipulating real elements through complex simulations. These computer activities determine a dynamic representation of three-dimensional data using articulated visualization techniques and using materials, lights, colors, tends to reproduce the characteristics of the real world.

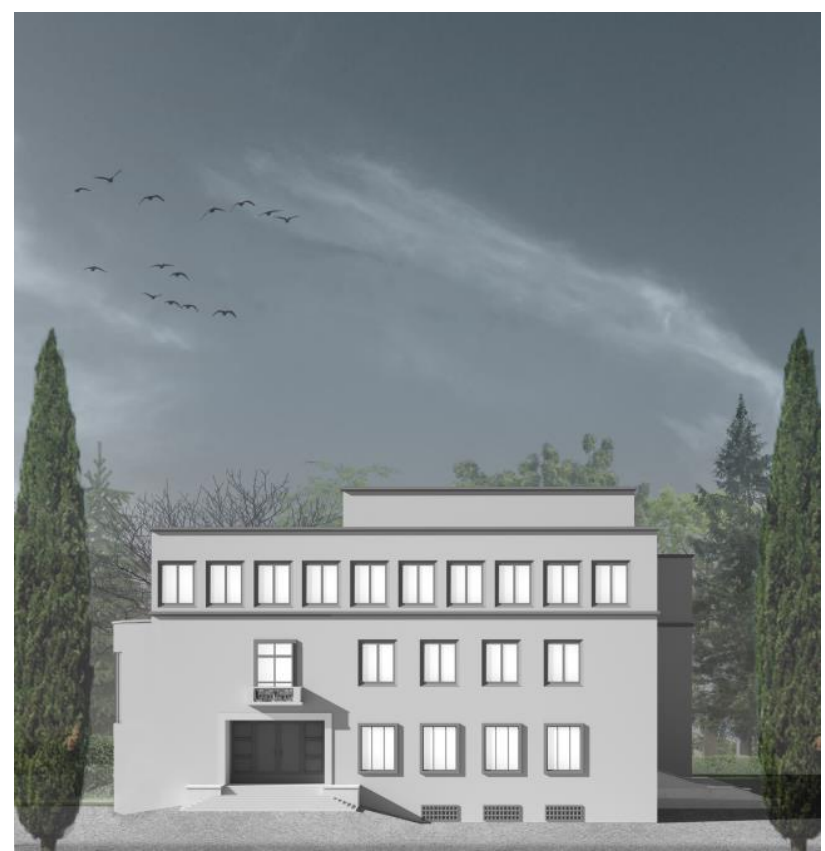

Figure 16. The Royal Park of Tirana. Render of the Villa Reale.

Of great interest is the primitive phase of the modelling that is the activity of three-dimensional transformation of the twodimensional graphics, which allows an immediate visualization of the geometric shapes and the basic volumes. These physical models constitute both geometrical configurations able to determine the volumes and bases with which to interact through photo-modelling. For the study of the Royal Park of Tirana, digital models of the Villa Reale, the Odeon, the Chapel, the generator's house, the gardener's house and the iron and glass greenhouse complex were created. The aforementioned models, appropriately processed and rendered using specific software, aim to verify the integration of survey techniques by comparing the measurements made. (Vokshi 2014)

\section{CONCLUSIONS}

The redrawing of the architecture and vegetation system of the Royal Park of Tirana in Albania constitutes a process of knowledge of the artefacts inherited from the past. Through a critical reflection on the architecture and landscape of the early twentieth century, through a graphic survey of the disciplinary sources of drawing, with attention to the themes of form, structure, innovation and representation, we tend to repeat, with a layout innovative, the redesign of some archival documents. The redrawing and the relative graphic documentation of the structures and of the vegetation system is proposed, therefore, as a universal language suitable to reveal the hidden meanings belonging both to the architectural system and to the territorial system, thus constituting the instrument of "revealing attitude" and "propensity design" for the representation of the real state of structures and vegetation. (Giordano 2015)

\section{REFERENCES}

Bulleri A., 2012, Tirana: contemporaneità sospesa, Macerata: Quodlibet, 2012, p. 204, ISBN: 9788874624201.

Corniello L., 2019, Il disegno del Parco Reale di Tirana. Napoli: La scuola di Pitagora editrice, 2019, p. 202, ISBN97888-6542-693-7.

Giacomelli M., Vokshi A., 2012. Architetti e ingegneri italiani in Albania, Firenze: Edizioni Edifir, 2012, p. 192, ISBN: 9788879705837 .

Giordano P., 2015. Il disegno della firmitas, Napoli: la Scuola di Pitagora, 2015, p. 275, ISBN 9788865424629.

Giusti M. A., 2012. "Villa Reale" di Tirana: architetture, giardini, arredi, opere d'arte, dai progetti del ventennio al progetto di restauro, in Giacomelli M., Vokshi A., Architetti e ingegneri italiani in Albania, Firenze: Edizioni Edifir, 2012, p. 192, ISBN: 9788879705837.

Nepravishta F., 2012. Il progetto di Giulio Bertè per la Villa Nepravishta, in Giacomelli M., Vokshi A., Architetti e ingegneri italiani in Albania, Firenze: Edizioni Edifir, 2012, p. 192, ISBN: 9788879705837.

Posca L., Barucci C., 2013. Architetti italiani in Albania (19141943), Roma: Clear, 2013, p. 298, ISBN: 9788838501104.

Vokshi, A., 2014. Tracce dell'Architettura Italiana in Albania 1925 - 1943, Firenze: DNA Editrice, p. 311, ISBN: 9788890394744 .

Revised January 2019 